\title{
The Role of Parents in Christian Religious Education on Adolescents' Morals
}

\author{
Darsono Ambarita ${ }^{1}$, Indra Sihole ${ }^{2}$, Benjamin Sihotang ${ }^{3}$ \\ (dart3024@gmail.com, indra.sihole@gmail.com, sihotang.benjamin@yahoo.co.id)
}

Sekolah Tinggi Pelita Kebenaran Medan

\begin{abstract}
The role of education is to educate and guide according to the needs of the participant to change towards a positive direction. The future of a nation lies in the hands of the young generation in that country therefore it is necessary to prepare them to develop the country and nation. As Christian teenagers it is necessary to have good morals in order to reflect the existing moral values in society. Obviously this is not detached from the role of parents in Christian religious Education to shape the morals of Christian teenagers to become better. Education starts at home functioning to develop ability and forming the character and civilization of a nation with dignity in education the nation's life purposed for the development of teenagers to become people of faith and dedicated to God.
\end{abstract}

Keywords: Christian Education, Morals

\section{Introduction}

Christian Religious Education consists of: Education, Religion, and Christian. Sudirman views education as an effort by an individual or group to influence people or group of people to be higher mentally. Education can take place in school, family, society, and church.

The definition of education is a conscious, systematic, and continuous effort to pass on, encourage or attain either knowledge, attitudes, values, skills or senses, or whatever result from that effort. Therefore education is a conscious effort performed by everyone to increase knowledge, skills, and to change from not good to good.

The word agama originated from Sanskrit, meaning not chaotic. Rudolf Pasaribu views religion a spiritual institution that can increase or unite human life, between man and between man and God. Religion in general is a complex relationship between belief, worship and ethical demands related to God. Religion is attached to an individual as an expression and fulfillment of personal belief that leads to salvation in the present and the future. The term Christian in theological dictionary, originates from Greek, i.e., Kristianos meaning follower of Christ. Christian education is an assistance given consciously or purposely to children by which they can grow and develop to maturity in terms of morality and Christian values upon Christian faith.

According to KBBI, morals is the wrong-right accepted by the public concerning action, attitude, obligation, etc.: dignity, manners. A person's morals is affected by his environment. If the environment is good, the person will have good morals and vice versa. In a family, the church and education domain, children receives moral teaching.

Therefore it is concluded that Christian Religious Education is education containing Christian teachings emphasizing the three aspects of education, namely knowledge, attitude 
and values and skills based on Christian faith. So that Christian religious education may develop proper morals in a child.

However, in reality the writer does not find these things, because what is happening around the Pinang Baris Terminal area where teenagers have very harsh characteristics and angry in their language and action, not honoring parents, and more shockingly like to gather in groups and gamble, steal, use narcotics, play truant and other negative actions. Teenagers get money by street entertainment, sweeping cars, and begging. These are the results of bad influence, in relationships interaction takes place between one person and another. This interaction will have mutual influence, whether good or bad.

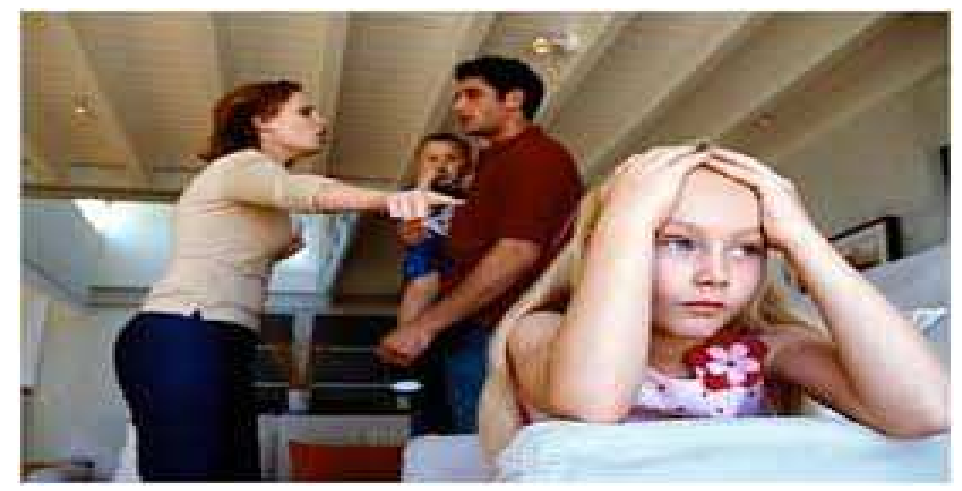

According to the author the best education begins in the family. It was found that the role of parents in educating teenagers was not carried out properly. Parents' life model do not have good life values, even parents tend to be rude/angry, rarely at home, household fights, gambling, drinking around the Pinang Baris Terminal. As a result teenagers do not experience the love and education of parents who are right. Consequently, the role of parents as educators, mentors will build faith in God so that it has a future.

Christian parent education plays the role of educator, he does not see his job as merely an educator, he does not see his task as merely teaching Christianity as religious knowledge, but also as life. But more than that, inculcation of Christian values must be the main focus in his task. So, here is the role of parents as educators so that teenagers grow properly:

a. Building faith

The task of parents as educators of faith at home has severe challenges, because it must guide children to achieve a more perfect level of human life. Therefore, besides being empathic (exploring students' thoughts and feelings). Become an inspiration who encourages children to develop into believers. Actual actions from parents are far more important than just theories. The more complete the concrete testimonies parents can give the more they will be trusted and emulated by teenagers.

b. Giving Guidance

The main function of guidance is to help teenagers in learning problems, relationships or problems of adolescent life. There are four kinds of guidance functions:

1) Preservatives: maintain and foster a good atmosphere and situation and continue to be strived for fluent teaching and learning.

2) Preventive: prevent before problems occur.

3) Curative: seek formation in overcoming problems

4) Reliability: hold a follow-up to the placement after adequate treatment is held. 
This task is an educational aspect, because it not only pleases knowledge, but also involves the development of personality and the formation of adolescent values. Then you must be able to recognize the problems faced by teenagers today.

c. Being a role model

Being a model is habituation in the form of daily behavior such as: dress neatly, speak good, praise, be polite. Parents set an example is a Teacher who has a personality and character that reflects the Christian faith. This has many roles. Attitudes and behavior in good and polite speech can make yourself favored by many people. The importance of politely speaking manners in teen relationships.

Not only as a teacher but can be a friend for teenagers so that teens are more open and parents get many opportunities to grow in faith.

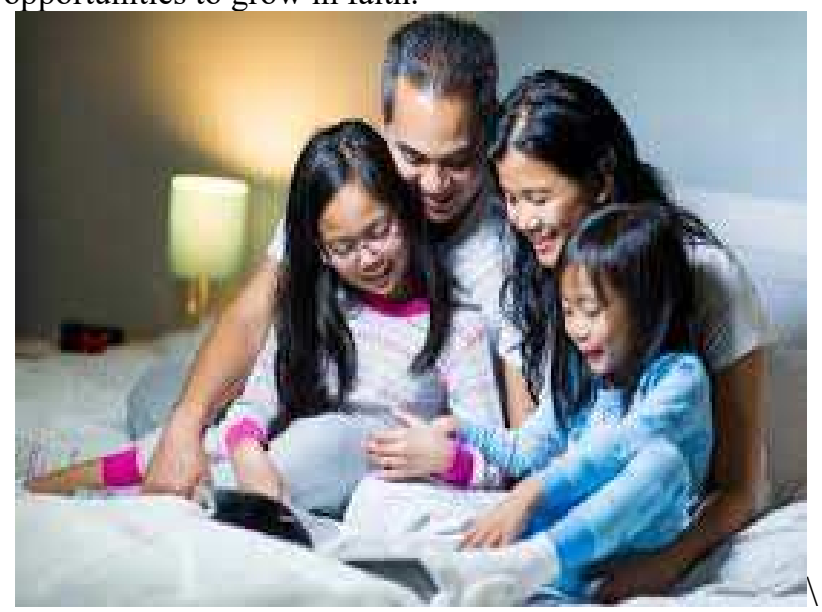

Attitudes are formed in various ways, including:

1) Through repeated experience reset, or can go through a experience accompanied by feelings depth.

2) Through imitation, imitation can occur accidentally, it can be intentionally.

3) Through suggestion, here someone forms an attitude towards the object without a reason and thought that comes from someone or something that has authority in his view

4) Through identification, someone imitates another person or an organization / body based on an emotional attachment; imitate in this case more in the sense of trying to match.

\section{RELETIONSHIP CHRISTIAN \\ EDUCATION AND MORAL}

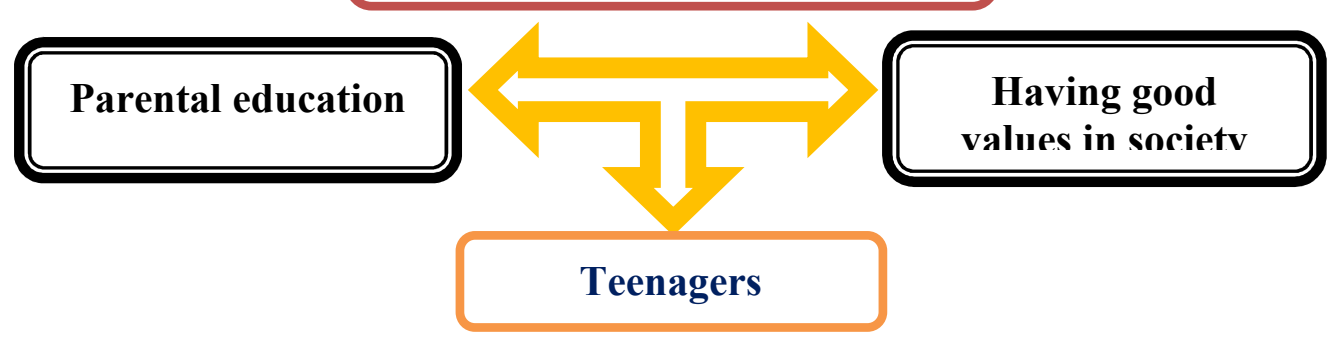




\section{Research Result}

The role of Christian Religious Education in parents is very important in the process of educating and guiding teenagers. Parents As educators have a great responsibility in educating adolescents in addition to education in general, also pay attention to spiritual life and character formation. Adolescent morals determine the impact of his life in everyday life. Adolescent morals that describe good values.

After conducting an assessment, both through literature studies and surveys, the results are obtained that the role of parents as educators in teaching Christian Religious Education. Furthermore, the spiritual growth of adolescents in Pinang Baris in the good category. This will certainly affect the results achieved. While for the level of influence between the role of parents in teaching Christian Religious Education on the spiritual growth of adolescents in Pinang Baris, there is a good influence. That is, the higher the level of the role of parents in teaching Christian Religious Education, the teenage spiritual growth tends to increase.

Based on the facts above, it suggests the implications that are expected to be an input for positive improvement for the role of parents in teaching Christian Religious Education and the spiritual growth of adolescents in Pinang Baris. The implications suggested to parents are the need to convey spiritual things about the basic teachings of God's Word such as love for God and others, and provide good examples from constructive words to daily behavior and continually encouraging teenagers to worship God.

Table 1.The role of parent Respondent Percentage

\begin{tabular}{ll}
\hline Negative & 45 \\
Positive & 15 \\
Total & 60 \\
\hline
\end{tabular}

Based on the table above, from 60 respondents, for 45 people $(51.6 \%)$ the influence of parents is positive; Positive impact seen in adolescents if Christian education is applied at home then the realization of good morals. Teenagers are not affected by juvenile delinquency, are diligent in school, like to worship, respect for parents and are active in positive activities in the environment and at school. For 15 people (48.4\%) the absence of a negative parental role, this shows that children are more likely to do negative things that harm themselves and others, make money prematurely, consume drugs, theft, gambling, are lazy to school and not love worship.

\section{Suggestion}

Based on the findings, the researchers provide advice to parents. The suggestions referred to are as follows:

1) For parents, they should equip themselves with God's Word to be able to educate teenagers in accordance with God's Word and be able to be good examples in words and deeds.

2) Parents are referred to as educators attending the Seminar on Adolescent Psychology because it is very necessary to add insight and understanding to each parent in terms of educating adolescents according to age stages. 


\section{References}

[1] Daniel Nuhamara, Pembimbing PAK Bandung: Jurnal Info Media, 2007

[2] https://kbbi.web.id/moral.html. di akses pada tanggal 22 januari 2018

[3] Hardi Budiyana, Dasar-dasar Pendidikan Agama Kristen. Yogyakarta: Gunung Mulia, 2011

[4] Abu Ahmadi dan widodo Supriyono. Psikologi Belajar -edisi revisi. Jakarta: Rineka Cipta, 2005

[5] E Mulyasa, Manajemen Pendidikan Karakter, Sinar Grafika Offset, Bandung, 2012 